Další autoři podávají analýzu některé z otázek Husovy nauky. Pavlína Cermanová sledovala nebiblická proroctví v Husových spisech a vyhodnotila, které texty mohl znát, i způsob jejich užití. Husovy názory na manželství a rodinu zpracovala Anna Paner. Klíčovým pojmem Husova učení je však především pojetí církve.

Na toto téma bylo už vydáno mnoho studií. Ve sledovaném svazku se ho týkají hned dvě. Paweł Kras podal rozsáhlý přehled tématu reformy církve, jak je navrhována u Viklefa a Husa. Pro polského čtenáře, a nejen pro něho, je to zásadní, dobře orientovaný přehled s početnými citáty z děl obou reformátorů. Martin Nodl se zamýšlí nad možností uplatnění Husovy představy církve predestinovaných v pozemské realitě a zkoumá, jakou odezvu mělo Husovo pojetí u dalších autorů husitské epochy.

Husovu predestinační teorii nenásledoval Jakoubek ze Stř́ibra, jemuž věnoval pozornost Dušan Coufal. Jeho východiskem byla Jakoubkova dosud nevydaná kvestie o koncilech. Coufal k ní představil široký kontext doby vzniku na jedné straně a na straně druhé přehled dobových znalostí o koncilech. Z jeho analýzy plyne, že Jakoubek i jeho druhové přistupovali ke koncilům historicky a pragmaticky. Výsledkem bylo převážně míjení evropského konciliaristického proudu a kritické vidění soudobých (podle Jakoubka fiktivních) koncilů, $\mathrm{z}$ nichž ten kostnický byl k husitům tak nepříznivý. Coufalova studie, jako u něho vždy založená na př́mém zpracování pramenů, je velmi hodnotným příspěvkem $\mathrm{k}$ tématu, které se v českém prostředí dosud nedočkalo dostatečné pozornosti.

Za tematický závěr svazku můžeme považovat př́spěvek Henryka Gmiterka o husovské a husitské tradici v polské Jednotě bratrské. Vedle připomenutí počátků Jednoty sleduje osudy její polské větve a míru připomínání Husa do konce 16. století.

Varšavský sborník nabízí vedle shrnujících příspěvků i několik badatelsky přínosných studií. Řadí se nepochybně k těm zdařilejším publikacím, jejichž vznik podnítilo husovské kulaté jubileum.

Blanka Zilynská

doi: $10.14712 / 23365730.2019 .23$

\title{
Dominik Opatrný, Zachránit lidi od hříchů. Etika v teologii mistra Jana Husa
} Jan Keřkovský - Mlýn, Jihlava 2018, 128 s., ISBN 978-80-86498-65-2

Nedávné kulaté výročí smrti Jana Husa vyvolalo v život mnoho publikací o něm, většinou shrnujících a bilančních. Nové badatelské výkony se objevují spíše výjimečně a dodatečně. Patř́ mezi ně i studie D. Opatrného. Jeho práce se věnuje různým otázkám z oboru etiky, viděným zorným úhlem spisů M. J. Husa.

První kapitola načrtává jeho životopisná data a hlavně představuje díla, v nichž lze příslušné myšlenky najít. Autor pracuje s texty editovanými v moderní formě i v edicích starobylých (od vydání z 16. stol.), do rukopisných textů nenahlížel. Pramenná základna je i tak dostatečně široká.

Vlastní analýza etické problematiky je rozdělena do devíti oddílů, které sledují jednotlivá témata Husovy etiky. Hus ovšem nezanechal spis věnovaný speciálně a soustavně morálnímu učení. Opatrný proto musel sestavit Husovy názory rozptýlené v různých dílech do logické struktury. Vycházel ze spisů, které bud' obsahují v tomto směru rozsáhlejší pasáže (např. O postačitelnosti zákona Kristova), nebo jen jednotlivé a dílčí výroky. 
Východiskem výkladu je otázka, proč se má usilovat o dobro a co dobro je. Husova odpověd' sleduje tradici křest’anských učitelů a zvláště Petra Lombarda. Základní kategorií je pro něho Zákon (přirozený, Kristův a lidský). Zákon Kristův, který je Pravdou, je dostupný v Písmu a představuje pro Husa nejvyšší mravní imperativ. Obsahuje řadu přikázání, tedy př́kazů, zákazů a rad, jež má křest’an zachovávat, aby jednal dobře, tedy mravně, a naplnil lidskou důstojnost, která člověku přísluši jako obrazu božímu.

Důležitou roli v Husově učení sehrálo řešení konfliktu autorit, tedy otázka poslušnosti vůči různým autoritám při jejich střetu s Písmem. Výklad obsahu Písma a jeho uplatnění v pozemské praxi vyžaduje zapojení úsudku člověka, tedy užití svobodné vůle - svědomí. Také roli svědomí věnoval Hus několikrát pozornost. Svobodu svědomí chápal jako právo člověka jednat podle toho, co ve svém svědomí poznává jako správné, svědomí bylo jeho osobním soudcem. Před koncilem v Kostnici Hus svědomím neúspěšně argumentoval (podrobně o tom na s. 61-63).

Autor se dále zabývá problematikou hříchů, které jsou propojené kauzálně (jeden vyvolává další) i ontologicky (jeden obsahuje i další). Závažnost hříšného jednání vedla Husa k výkladu o mechanismu účinného pokání a teorie moci klíčů. Tematika křest’anských cností vycházela v Husově myšlení z učení Johna Wyclifa a souvisela s jeho kritikou církevní disciplíny a apelem na nejvyšší autoritu Písma, jíž nesmí odporovat žádný zákon.

Při četbě Opatrného knihy se historik nejen poučí o názorech Jana Husa na uvedené etické otázky, ale uvědomí si také, že pojmy dnes užívané měly v kontextu středověké učenosti jiný význam. V daném př́ípadě je to vedle Pravdy (chápané nikoli jako shoda s realitou, nýbrž jako Pravda Boží zachycená Písmem) především pojem svědomí a teorie ctností. Sedm křest’anských ctností bylo chápáno jako dary Ducha (vlité od Boha nebo získané), které spojovala láska jako nejvyšší ctnost. Hříšník ztrácí ctnosti a milost Boží, i když svátosti poskytované hříšným knězem samy o sobě platnost neztrácejí.

Hus své názory na etické otázky uplatňoval samozřejmě i v praxi, a to především při své kazatelské činnosti. Opatrného kniha ukazuje, že Husovy projevy nabádající k opuštění hříšného života nebyly jen obyčejným ,,moralizováním“, nýbrž vycházely z hluboce promyšlených představ o propojenosti hř́íchů a jejich následcích: ztrátě milosti, zásluh a ctností.

Analýza etické problematiky dala tak nahlédnout do souvislostí některých Husových postojů. Umožňuje pochopit jeho jednání a nakonec i jeho rozhodnutí jít na smrt, aby nejednal proti vlastnímu svědomí. Husův důraz na svědomí je považován za jeden z jeho odkazů dnešku.

doi: $10.14712 / 23365730.2019 .24$

\section{Adéla Šmilauerová, Bosí augustiniáni v Čechách jako objednavatelé uměleckých děl v 17. a 18. století \\ Opera Facultatis theologiae catholicae Universitatis Carolinae Pragensis. Historia et historia artium, vol. XXX, Nakladatelství Lidové noviny, Praha 2018, 244 s., ISBN 978-80-7422-639-7}

Kniha kunsthistoričky Adély Šmilauerové, která v současné době pracuje jako archivářka Ústředního archivu Českobratrské církve evangelické, přináší první odborné zpracování 